Journal of the Textile Institute Proceedings and Abstracts

\title{
IRISH SECTION: Meeting at Belfast, 14th March, 1919: Mr. J. G. Crawford in the Chair: ATMOSPHERIC HUMIDITY IN ITS RELATION TO ELECTRICAL PHENOMENA IN TEXTILE MATERIALS
}

\section{S. A. Shorter D.Sc.}

To cite this article: S. A. Shorter D.Sc. (1919) IRISH SECTION: Meeting at Belfast, 14th March, 1919: Mr. J. G. Crawford in the Chair: ATMOSPHERIC HUMIDITY IN ITS RELATION TO ELECTRICAL PHENOMENA IN TEXTILE MATERIALS, Journal of the Textile Institute Proceedings and Abstracts, 10:8, 218-219, DOI: 10.1080/00405001908630922

To link to this article: http://dx.doi.org/10.1080/00405001908630922

曲 Published online: 24 Nov 2008.

Submit your article to this journal $₫$

Џ Article views: 2

Q View related articles ¿

Citing articles: 1 View citing articles ๔ 
given length of warp; also a record of shrinkage from reed to cloth width, so as to fix the correct number of warp threads when remaking. It is a matter of common knowledge that the allowances for rents, rates, taxes, coel, oil, discounts, bank interest, depreciation, \&c., are usually added to the quotation costs pro rata to what is paid for weaving. As a general rule, this is a good system, but it is essential to make sure that the charges are in correct proportion to wages, and this ratio must be varied according as to whether the cloth has more or less picks in ratio to warp threads, and particularly as to whether the cloth requires any special make, or width of loom, or other extra charges, such as more costly yarns, which may not necessarily enhance the weaving cost.

Departmental costs must be carefully revised from time to time, and any wasteful or uneconomical process eliminated as far as possible.

I feel that I ought to refer, briefly, to some present. day features of mill organisation as they affect the social conditions of the workpeople. Most of these welfare schemes are natural developments of the National Health Insurance Act, just as that was preceded by the Employers' Liability and Workmen's Compensation Acts. Any organisation which will bring employer and employed into closer touch, and to act in mutual co-operation for the good of each, is very desirable. I trust that, ultimately, some sound system of profitsharing will be devised in every industry, whereby the worker may benefit by any contribution he makes to setisfactory results, but at the same time allowing capital to be so strong as to enable it to benr the charge of fluctuating margins to which trade on a large scale always seems to be extremely liable. I am very atrongly in favour of works being so organised as to permit of young persons taking full advantage, even before they become compulsorv of the Fisher Education Act Clauses which require all young persons to attend school for at least 320 hours per year between the ages of 14 to 16 , and, ultimately, to 18 years of age.

With a little careful adjustment, and some mutual give-and-take on the part of the operatives and the employer, I am convinced that more efficiency will be secured, but whilst the employer is called upon to bear such extra costs as payment for time spent at school, it is essential that the operative must, in turn, cease to restrict output, and must be prepared to co-operate with the management in allowing the best qualified persons to be placed in the most responsible positions.

I trust my remarks will be the means of causing each member of the Textile Institute to realise that the industry with which we are connected is one which requires to be highly organised, and that efficiency in this respect will result in increased benefit to both employer and employed.

\section{Discussion.}

The Charrman expressed satisfaction on account of the good attendance at the opening lecture in connection with the Section, and hoped it would be the forerunner of many interesting and instructive evenings. $\mathrm{He}$ referred to the outlook with regard to export trade to America and said that in this country the closest attention would have to be given to our organisation methods. Mr. Crompton had come amongst them because he had the objects of the Institute and the trade of the country at heart, and, for his services, they owed him their warmest thanks. Most of them realised that pre-war methods and standards would not suffice for the future. In the past, if a manufacturer thought he had a good thing, or had devised an advantageous method, he was inclined to keep it to himself, but the time had come for real recognition of the shortsightedness of such a policy. We did not sufficiently realise that the interests of all were bound up in the securing and adoption of the best methods.

A number of questions were answered by $\mathrm{Mr}$. Crompton, and a hearty vote of thanks was passed to the lecturer and chairman.

\section{IRISH SECTION}

Meeting at Belfast, 14th March, 1919.

Mr. J. G. Crawford in the Chair.

\section{ATMOSPHERIC HUMIDITY IN ITS RELATION TO ELECTRICAL PHENOMENA IN TEXTILE MATERIALS}

By S. A. Shorter, D.Sc.

Static electricity is a well-known source of trouble in a large number of textile processes. The extent of the trouble depends very largely on the degree of humidity of the atmosphere. In a very dry atmosphere, such as is found in many parts of the world, it would be quite impossible to carry out successfully most textile processes. This question of natural atmospheric humidity has been one of the factors determining the position of the great textile centres of the world. Thus, Lancashire is an ideal place for cotton spinning owing to the fact that the natural humidity is high and does not fluctuate much throughout the year.

The modern view of static or so-called frictional electricity is that it is an intensification of the feeble, natural surface electrification produced by the intimate contact which occurs during friction or when two bodies are pressed together. This intensification or heaping up of the naturai surface charge can only occur on a body which is a non-conductor of electricity. The conductivity of textile materials depends upon the amount of moisture they contain-which, in turn, depends upon the humidity of the atmosphere to which they are exposed. Thus, wool exposed to an atmosphere of 73 per cent humidity, at $65 \mathrm{deg}$. Fah., will contain about 16 per cent of moisture ("regain ") and will normally exhibit very little electrification. On the other hand, wool exposed to an atmosphere of 25 per cent humidity, at 65 deg. Fah., will contain about 8.5 per cent of moisture and will be readily electrified. The absorption of moisture by textile materials depends also on the temperature; for a fixed percentage humidity of the atmosphere the equilibrium condition is greater the lower the temperature. In spite of this 
fact, however, the electrification of wool increases as the temperature is lowered below $60 \mathrm{deg}$. Fah., owing to the resultant harshness of the fibre.

The most suitable degree of humidity varies for the different processes. In the case of cotton, for the procesees preparatory to spinning, a humidity of 62 per cent, at temperatures from $70 \mathrm{deg}$. to $80 \mathrm{deg}$., is most suitable. For spinning, rather less humidity -52 per cent, at from $80 \mathrm{deg}$. to $90 \mathrm{deg}$.-is required. In the case of worsted drawing, a humidity of 70 per cent is gufficient to diminish, very largely, electrical effects in normal cases. Such a degree of humidity, however, leads, in the epinning, to trouble from other causes, so a lower degree is more suitable-about 50 per cent. As in many mills such a degree of humidity occurs naturally on most days of the year, it often occurs that where artificial humidification is adopted in the drawing, it is not used in the spinning. Humidification in the drawing is, of course, indirectly of value in the spinning, in that it obviates excessive loss of moisture during the drawing.

In the weaving of cotton and linen goods, much higher degrees of humidity are required than in drawing and spinning. Thus, in weaving heavily-sized cotton yarns, 88 per cent humidity may be required. The object of such a high degree of humidity is not, however, the elimination of electrical effects, but the maintaining of the size in a suitably soft condition.

Though humidification diminishes electrical effects; it does not always effect a perfect cure. Thus, in worsted drawing and spinning, trouble may occur, even in humid atmospheres, if the wool fibre, owing to its previous treatment, has been brought into a readily electrifiable state, and this trouble is further aggravated by increased speed of the machinery. Conversely, the wool fibre may be brought into such a state that it does not electrify, appreciably, even in comparatively dry atmospheres.

\section{Discussion.}

In reply to Mr. A. W. Metcalie, the author stated that coarse wools were not more liable to give electrcial trouble than fine wools, though there were differences in this respect between different varieties of fine merino wools.

Replying to further questions, the author said :

Methods of humidification in which the air is conditioned before entering the room do not give rise to the deposition of drops of water on the machinery, a trouble which sometimes occurs with "water-spray" methods of humidification.

The effect of humidification on the health of the operatives has been pretty well investigated, and it is now recognised that a properly designed and regulated system is free from objection on this score.

Increased speed of the machinery has a great effect in increasing electrical trouble, so that in cases where electrical trouble is a factor limiting speed, its elimination will give rise to increased output.

Mr. F. Anderson (Portadown) said the whole problem was of profound interest, and investigation should be carried forward. He moved a vote of thanks to the Lecturer and Chairman.

Mr. Metcalfe seconded, and the vote was heartily accorded.

The Chairman returned thanks, and said he realised that the whole question was of much greater importance than he was prepared to concede before hearing the lecture. These Institute lectures were of real importance and he always left with the hope that the same lecturers would again visit them.

\section{YORKSHIRE SECTION}

Meeting at Bradford, 24th July, 1919.

\section{Mr. George Garnetr in the Chair.}

At this meeting the first business under consideration was the election of the Committee of the Section. A record of attendances during 1918 was presented, and it was ultimately decided that it was advisable to reduce the number to fifteen, the Committee to retain power to add to this number. The following gentlemen were elected:-J. H. Bates, R. J. H. Beanland, A. M. Bell, G. R. Broomhead, G. L. Craig, Geo. Garnett, G. R. Gaunt, F. Hartley, E. T. Holdsworth, E. Midgley, G. T. Oldham, H. Pepper, J. Robinson, H. M. Sutcliffe, and John F. White.

It was decided that the Committee should meet on the Monday following to elect Chairman and ViceChairman.

Regarding the Hon. Secretaryship of the Section it was decided that Mr. E. T. Holdsworth be approached, and that Messrs. Garnett, White, and Craig form a deputation.

It was decided to hold six monthly meetings of the Section, from October to March next inclusive, for the delivery of papers and lectures, and the Secretary was instructed to communicate with proposed speakers on the following subjects:-(1) Bradford-"The Consular System "; (2) Batley - "Electricity Supply" ; (3) Leeds-" Financial Outlook" ; (4) Huddersfield"Production and Prices" ; (5) Halifax-" Economy in Steam Using "; (6) Bradford-" Dyes Situation," 